\title{
RISET TERINTEGRASI KONDISI LINGKUNGAN PERAIRAN SITUS KAPAL TENGGELAM SS AQUILA DI TELUK AMBON, INDONESIA
}

\section{INTEGRATED RESEARCH ON SS AQUILA SHIPWRECK SITE ENVIRONMENTAL CONDITION IN AMBON BAY, INDONESIA}

\author{
Guntur A. Rahmawan, Ulung J. Wisha, Wisnu A. Gemilang, Koko Ondara,
} Nia N. H. Ridwan \& Gunardi Kusumah

Loka Riset Sumber Daya dan Kerentanan Pesisir

Jalan Raya Padang-Painan km.16 Bungus Teluk Kabung, Padang

e-mail : guntura06@gmail.com

Diterima tanggal: 30 November 2017 ; diterima setelah perbaikan: 8 April 2019 ; Disetujui tanggal: 10 April 2019

DOI: http://dx.doi.org/10.15578/jkn.v14i1.6276

\section{ABSTRAK}

\begin{abstract}
Situs kapal tenggelam Steam Ship (SS) Aquila atau SS Duke of Sparta merupakan salah satu situs peninggalan arkeologi bawah air yang berada di Teluk Ambon. Saat ini, situs SS Aquila mulai dikenal sebagai salah satu lokasi penyelaman kapal tenggelam oleh para penyelam lokal dan internasional. Lokasi Situs SS Aquila terletak di dalam kawasan terminal pertamina dan berada pada jalur lalu lintas laut. Selain itu, banyaknya muara sungai yang dapat menimbulkan berbagai permasalahan yang berdampak negatif terhadap keberadaan situs tersebut. Penelitian terintegrasi di situs arkeologi bawah air tersebut sangat dibutuhkan untuk mengetahui permasalahan terhadap situs SS Aquila dalam pengembangan potensi wisata di Teluk Ambon. Riset dilakukan secara terintergasi meliputi pendekatan arkeologi laut yaitu kegiatan penyelaman, videografi bawah air, pelaksanaan survei hidrooseanografi dan pengamatan dengan Side Scan Sonar. Posisi situs SS Aquila berada pada kedalaman 15-35m. Kondisi badan kapal masih cukup utuh di beberapa bagian, namun beberapa bagian kapal telah hancur dan hilang seperti crane, cerobong, dan propeller. Berdasarkan hasil penelitian terintregrasi tersebut, bahwa situs SS Aquila dapat dikembangkan sebagai lokasi wisata selam minat khusus (kapal tenggelam). Akan tetapi, sejumlah upaya untuk pengembangannya perlu dilakukan pengkajian lebih lanjut terhadap nilai historis situs dan tingkat kerentanan kawasan situs. Dalam upaya pelestarian situs SS Aquila direkomendasikan kepada pemerintah setempat untuk memberikan pemahaman tentang pentingnya situs arkeologi laut, dan pelatihan terkait wisata selam kapal tenggelam berkelanjutan kepada pelaku wisata dan masyarakat.
\end{abstract}

Kata kunci: Situs kapal tenggelam, SS Aquila, Teluk Ambon, SS Duke of Sparta, arkeologi bawah air.

\section{ABSTRACT}

The Steam Ship (SS) Duke of Sparta or SS Aquila shipwreck site is one of the underwater cultural heritages (UCH) discovered in Ambon Bay that well-known as one of shipwreck diving sites by domestic and international divers. Nevertheless, located within Pertamina port of fuel and beneath the sea lanes of Ambon Bay makes this shipwreck site prone. Besides, a lot of estuaries in this area causes issues, which negatively impacts the existence of SS Aquila shipwreck site. Integrated research is essential to determine the recent condition of SS Aquila in term of marine tourism in Ambon Bay. The study was done by employing underwater archaeological methods such as diving, underwater videography, hydro-oceanography survey, and Side Scan Sonar (SSS). SS Aquila was submerged in the depth of 15-35 $\mathrm{m}$. The main body of this ship is slightly intact in some parts. However, the other parts of the ship have been collapsed and disappeared such as crane, chimney, and propeller. According to the results, SS Aquila shipwreck site can be developed as a shipwreck diving tourism with a specific requirement. Moreover, some efforts are necessary to develop this site in the form of historical studies and its regional vulnerability analysis. For SS Aquila preservation, it is recommended to local governments to socialize an understanding on how underwater cultural heritages are important, and create sustainable trainings related to the shipwreck diving tourism for local community and society.

Keywords: SS Aquila, shipwrecck site, environmental condition, Ambon bay, SS Duke of Sparta. 


\section{PENDAHULUAN}

Indonesia merupakan negara yang kaya akan warisan budaya dan dibuktikan banyaknya peninggalan masa lampau yang terbagi dalam masa sejarah - prasejarah, klasik, islam, kolonial, revolusi (Handoko, 2007). Indonesia sebagai negara maritim mempunyai potensi sumber daya di kawasan pesisir salah satunya adalah arkeologi bawah air yang memiliki potensi besar sebagai warisan budaya bawah laut (Underwater Cultural Heritage) namun tantangan terhadap pengelolaan pelestariannya juga sangat tinggi (Carducci, 2002).

Menurut Keputusan Presiden RI Nomor 19 Tahun 2007 pada pasal 1 ayat 1 bahwa Benda Muatan Kapal Tenggelam (BMKT) adalah benda berharga yang memiliki nilai sejarah, budaya, ilmu pengetahuan, dan ekonomi yang tenggelam di wilayah perairan Indonesia ZEE, dan Landas kontinen Indoensia, paling singkat berumur 50 tahun. Salah satu warisan budaya bawah laut di Indonesia yang memiliki tantangan dalam pelestarian yaitu situs kapal tenggelam Steam Ship Duke of Sparta (SS Aquila) yang terletak di kawasan perairan Teluk Ambon, tenggelam pada tahun 1958 saat pemberontakan Perdjuangan Rakjat Semesta (PERMESTA). Kapal tersebut tenggelam karena di bom oleh pesawat Douglash B26 Invader (Turang, 2016).

Situs kapal tenggelam dapat dimanfaatkan sebagai obyek penelitian dalam penelusuran nilai sejarah yang berkaitan erat dengan pengembangan karakter daerah dan bangsa untuk memperkokoh jati diri bangsa (Ardiwidjaja, 2017). Pengembangan kawasan wisata bahari merupakan suatu bentuk pengelolaan kawasan wisata yang memberikan manfaat bagi pengusaha di bidang perlindungan, pelestarian serta jasa lingkungan sumberdaya kelautan (Koriyandi et al., 2016).

Permasalahan yang berkaitan dengan sumber daya pesisir di Indonesia diantaranya adalah masih kurangnya kegiatan sosialisai betapa pentingnya menjaga warisan budaya bawah laut dan penerapan IPTEK yang terkait guna mendukung pemanfaatan sumber daya pesisir yang berkelanjutan. Penelitian terintegrasi ini bertujuan untuk mengetahui kondisi terkini beberapa situs arkeologi bawah laut yang ada di area penelitian, mengetahui aspek-aspek pendukung dan penghambat kelestarian situs kapal tenggelam $S S$ Aquila. Kegiatan tersebut dilakukan sebagai upaya perlindungan terhadap situs arkeologi bawah laut, serta dapat dijadikan sebagai bahan rekomendasi dan parameter dalam pengembangan kawasan konservasi maritim yang ada di perairan Teluk Ambon.

Kapal kargo Duke of Sparta diluncurkan pada tahun 1940 dari galangan kapal William Gray, West Hartlepool dan dijual pada tahun 1951 untuk sebuah perusahaan Italia dari Napoli dan berganti nama SS Aquila. Kapal SS Aquila merupakan target dari sasaran pemberontakan PERMESTA yang terjadi saat itu. Tujuan pengerusakan dan penenggelaman kapal-kapal kargo di perairan Teluk Ambon adalah untuk melemahan ekonomi Indonesia demi kepentingan PERMESTA. Peristiwa ini merupakan salah satu peristiwa penting bagi perjalanan hubungan Amerika dengan Indonesia (Turang, 2016).

\section{BAHAN DAN METODE}

\section{Lokasi penelitian}

Lokasi penelitian berada di Teluk Ambon, termasuk dalam wilayah administrasi kota Ambon, Maluku, Indonesia dengan letak geografis $3^{\circ} 37$ " $48^{\prime \prime}$ LS- $3^{\circ} 45^{\prime} 43^{\prime \prime}$ LS dan $128^{\circ} 14^{\prime} 02^{\prime \prime}$ BT - $128^{\circ} 00^{\prime} 34^{\prime \prime}$ 'BT. Wilayah teluk ambon dibagi menjadi 2 bagian yaitu Teluk Ambon Dalam (TAD) dan Teluk Ambon Luar (TAL) (Gambar 1). Penelitian dilaksanakan dalam 3 kali kegiatan survey yaitu pada 4- 9 Mei 2016, 16-24 Mei 2016, dan 1-4 Juni 2016 dan di fokuskan pada lokasi terdapatnya situs kapal tenggelam Duke of Sparta (SS Aquila).

\section{Metode Penelitian}

Penelitian dilakukan dengan metode dan pendekatan arkeologi maritim bawah laut melalui kegiatan-kegiatan penyelaman, videografi (2160p: 3840x2160 pixel), serta survei hidro-oseanografi dengan pengukuran ADCP (Acoustic Doppler Current Profiler), data logger, echosounder, dan pengukuran kualitas perairan serta pengamatan dengan Side Scan Sonar (SSS) kegiatan pengambilan data di lapangan dilakukan pada $18 \mathrm{~s} / \mathrm{d}$ 24 Mei 2016.

Pencarian lokasi Kapal tenggelam SS Aquila selain dengan metode penyelaman juga dilakukan pengamatan menggunakan alat Side Scan Sonar (SSS) untuk mengetahui posisi, arah, serta dimensi kapal. Pengambilan data hidrodinamika perairan sekitar situs dengan menggunakan alat Acoustic Doppler Current Profiler (ADCP) dan HOBOware (https:// www.onsetcomp.com/products/software/bhw-pro) selama 1 bulan dengan perekaman data tiap 10 menit untuk mengetahui kondisi kecepatan dan arah arus serta suhu perairan. Data pasang surut diolah untuk mengetahui tidal range dan analisis Indian Spring Low 


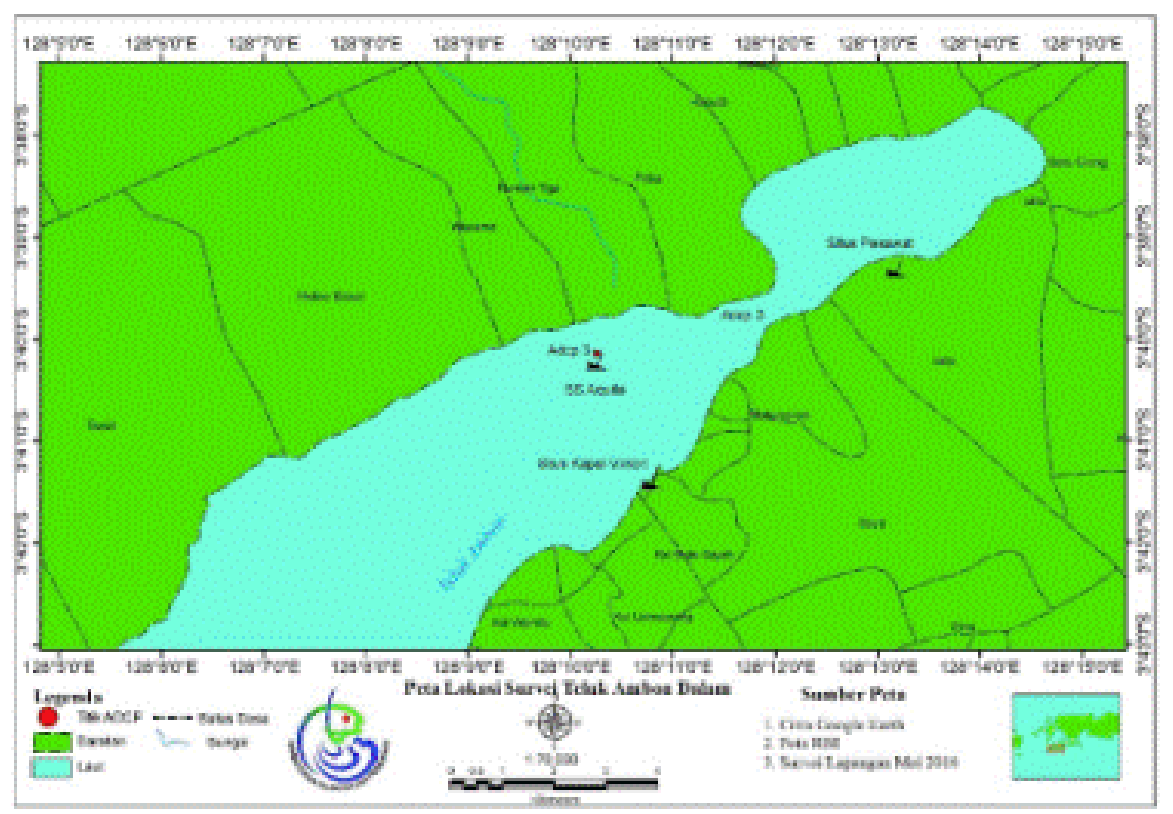

Gambar 1. Peta lokasi penelitian.

Figure 1. Map of research location.

Water (ISLW) (Adibrata, 2007). Posisi dan kedalaman Perairan Teluk Ambon didapatkan dari survei batimetri dengan mengunakan alat Echosounder Echotrack CVM Teledyne Odom Hydrographic Single Beam yang memancarkan frekuensi akustik ke dasar perairan laut untuk mendapatkan data kedalaman secara real time (Soeprapto, 1999).

Pengukuran kualitas perairan permukaan dilakukan secara in situ menggunakan alat Water Quality Checker (TOA DKK Tipe WQC-24) dengan 45 titik yang tersebar di perairan Teluk Ambon Dalam maupun Teluk Ambon Luar pada satu siklus pasang surut sebanyak tiga kali pengulangan pada setiap stasiun. Parameter yang diukur adalah parameter fisika perairan berupa suhu, konduktivitas, kekeruhan, dan parameter kimia perairan meliputi $\mathrm{pH}$, salinitas, densitas, dan Dissolved Oxigen (DO). Metode pengukuran kualitas perairan serta pengambilan sampel dilakukan pada kedalaman perairan yang berbeda-beda yaitu kedalaman $4 \mathrm{~m}$ dan $16 \mathrm{~m}$ menggunakan botol nansen. Pengambilan dan pengukuran kualitas air dilakukan secara in situ.

Sampel perairan tersebut dianalisis di laboratorium untuk menentukan nilai $\mathrm{pH}$, TSS, salinitas, dan kekeruhan. Perhitungan hasil pengamatan kualitas perairan diolah dengan menggunakan metode STORET dan mengikuti Standar Baku Mutu Kepmen LH No. 51 Tahun 2004 yang diperuntukkan untuk wisata bahari.

Pendekatan arkeologi bawah air dilakukan dengan kegiatan visualisasi dan videografi serta pengamatan visual lingkungan sekitar SS Aquila untuk mengetahui kondisi terkini badan kapal serta kerentanan yang bisa mengancam situs kapal tenggelam tersebut seperti pencemaran lingkungan perairan yang menyebabkan berkurangnya kualitas perairan laut pada kawasan tersebut. Penyelaman kapal karam SS Aquila direkomendasikan bagi penyelam level 2 (bersertifikat) dan level 3 (bersertifikat, berpengalaman serta minimal 30x penyelaman, bersertifikat lanjutan). Wawancara dilakukan dengan dinas setempat maupun masyarakat sekitar kawasan Teluk Ambon sebagai narasumber terkait keberadaan situs arkeologi bawah laut.

\section{HASIL DAN PEMBAHASAN}

\section{Kondisi Situs SS Aquila}

Posisi kapal karam SS Aquila bagian atas terdapat pada kedalaman 15-35 m dengan posisi haluan menghadap Barat Daya dan terdapat pada Teluk Ambon Luar. Bagian kapal masih terlihat utuh namun ada beberapa bagian terlihat rubuh, seperti tiang crane, cerobong dan dinding pada tiang crane. Badan kapal tampak berlubang akibat aktifitas manusia serta ditutupi oleh karang.

Tim penyelam sekilas memasuki bagian dalam kapal dan menemukan bagian mesin kapal masih terlihat utuh, selain itu juga masih terdapat adanya kabelkabel bagian mesin kapal dan tangga-tangga tempat awak kapal turun ke bagian mesin, bagian tersebut dapat ditemukan pada kedalaman $\pm 40 \mathrm{~m}$, sementara propeller kapal sudah tidak ditemukan lagi. 


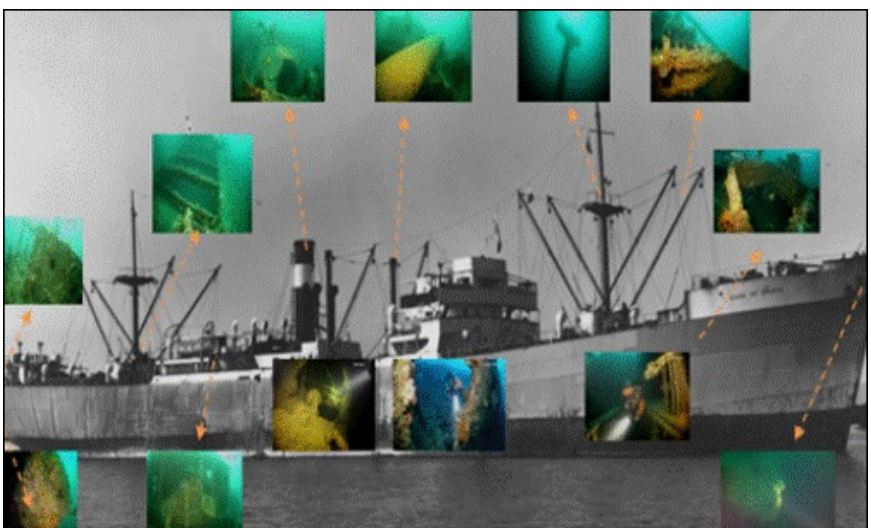

a)

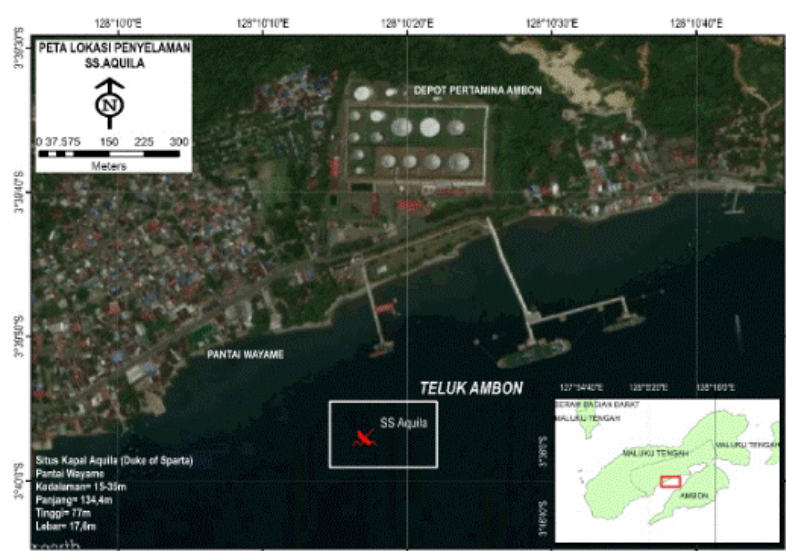

b)

Gambar 1. Kondisi terkini situs SS Aquila

(a) Keadaan kondisi beberapa bagian kapal sebelum dan sesudah tenggelam ditunjukkan dengan tanda panah, (b) lokasi penyelaman situs kapal tenggelam SS.Aquila (Sumber: Wisha et al., 2017).

Figure 1. The latest conditions of the SS Aquila site.

(a) The condition of some parts of the ship before and after drowning is indicated by an arrow, (b) the dive site of the sinking ship site SS.Aquila (Source: Wisha et al., 2017).

Berdasarkan informasi dari warga dan penyelam setempat, telah terjadi penjarahan bagian kapal $S S$ Aquila dengan menggunakan alat tradisional dan diduga yang diambil adalah propeller kapal yang mempunyai nilai ekonomi tinggi. Papan nama kapal yang melekat pada kapal untuk mengidentifikasi nama kapal tidak dapat ditemukan kemungkinan karena tertutup oleh terumbu karang.

Dimensi kapal SS Aquila berukuran besar dengan dimensi 17,6 m x 134,4 m x 7,7 m (Gambar 2) dan berada pada lereng yang masih memungkinkan dilakukan penyelaman pada kondisi tertentu. Kondisi perairan Teluk Ambon ditandai banyaknya biota laut yang dapat tumbuh dan hidup di kerangka kapal SS Aquila. Hasil penggabungan dari 3 lintasan Side Scan Sonar, telah memperlihatkan secara utuh gambaran kapal SS Aquila dari bagian depan sampai belakang. Arah kapal berada pada posisi haluan Timur LautBarat Daya dan berada pada titik koordinat 407980 E; 9594745 N UTM zona 52S di Teluk Ambon pada kedalaman 15-35 m.

\section{Potensi dan Kerentanan Kawasan Situs SS Aquila}

Keberadaan kapal mulai terlihat pada kedalaman $10 \mathrm{~m}$ dpl. Arus di sekitar kapal karam SS Aquila termasuk dalam kategori arus longshore dengan kecepatan arus rata-rata antara $0,09 \mathrm{~m} / \mathrm{dt} \mathrm{sd} 1,46 \mathrm{~m} / \mathrm{dt}$ dan termasuk dalam kategori lemah. Tabel 1 menyajikan kecepatan arus pada beberapa kedalaman pada kapal karam $S S$ Aquila.
Tinggi gelombang di perairan Teluk Ambon berkisar antara 0,04-0,5 m. Berdasarkan pada matrik klasifikasi penyelaman.

Arus di sepanjang kapal SS Aquila termasuk arus lemah dengan suhu antara $26^{\circ}-29^{\circ} \mathrm{C}$. Jarak pandang visibility pada saat penyelaman sekitar $10 \mathrm{~m}$. Berdasarkan pengamatan yang dilakukan oleh penyelam setempat kegiatan penyelaman sebaiknya dilakukan pada Oktober sampai November karena pada bulan tersebut cuaca di Teluk Ambon sangat cerah.

Kecepatan arus di Teluk ambon cukup bervarasi pada taip kondisi ekstrim pasang surut, dimana berkisar antara $0-1,12 \mathrm{~m} / \mathrm{s}$ pada kondisi pasang perbani, $0-1,2$ $\mathrm{m} / \mathrm{s}$ pada kondisi pasang purnama, $0-0,22 \mathrm{~m} / \mathrm{s}$ pada kondisi surut perbani dan berkisar antara $0-0,42 \mathrm{~m} / \mathrm{s}$ pada konsisi surut purnama.

Tabel 1. Kecepatan arus pada kedalaman sekitar 25 m, 20

$$
\mathrm{m}, 15 \mathrm{~m}, 10 \mathrm{~m}
$$

Table 1. Current velocity at depths of about $25 \mathrm{~m}, 20 \mathrm{~m}, 15$ $m, 10 m$

\begin{tabular}{llll}
\hline $\begin{array}{l}\text { Kedalaman } \\
(\mathbf{m})\end{array}$ & $\begin{array}{l}\text { Rata-rata } \\
(\mathbf{m} / \mathbf{d t})\end{array}$ & $\begin{array}{l}\text { Min } \\
(\mathbf{m} / \mathbf{d t})\end{array}$ & $\begin{array}{l}\text { Max } \\
(\mathbf{m} / \mathbf{d t})\end{array}$ \\
\hline 25 & 0,53 & 0,018 & 2,14 \\
20 & 0,19 & 0,005 & 1,7 \\
15 & 0,1 & 0,006 & 0,53 \\
10 & 0,13 & 0,007 & 1,46 \\
\hline
\end{tabular}


Tipe pasut di perairan Teluk Ambon adalah pasut campuran condong harian ganda dengan nilai $\mathrm{F}=0,602$ hal tersebut terlihat dari besarnya nilai amplitudo pada konstanta pasut campuran M2 55,16 dengan beda fasa paling tinggi sebesar $207,24^{\circ}$. Mean Sea Level (muka laut rata-rata) perairan Teluk Ambon sebesar 124,76 $\mathrm{cm}$, Zo sebesar $148,72 \mathrm{~cm}$ dan nilai Chart Datum $-23,96 \mathrm{~cm}$. Data hasil pemetaan batimetri menunjukkan bahwa kedalaman perairan Teluk Ambon termasuk dalam kategori perairan dalam terutama pada bagian Teluk Ambon Luar hingga ke Laut Banda dengan ratarata kedalaman antara 100 - 500 m (Gambar 4).

Keadaan dasar laut di Perairan Teluk Ambon Luar sangat curam bila ditarik dari garis pantai pada bagian tengah-tengah teluk, dengan interval kontur yang rapat.

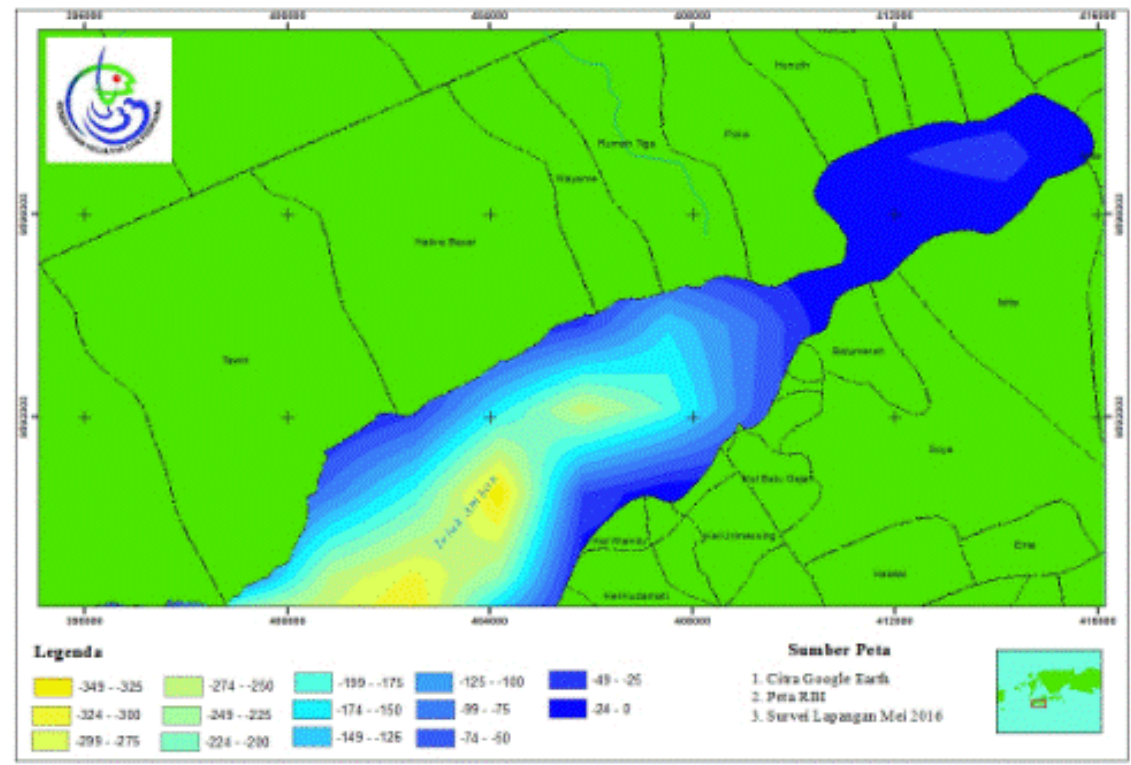

Gambar 3. Peta batimetri sekitar SS Aquila.

Figure 3. Bathymetric map around SS Aquila.

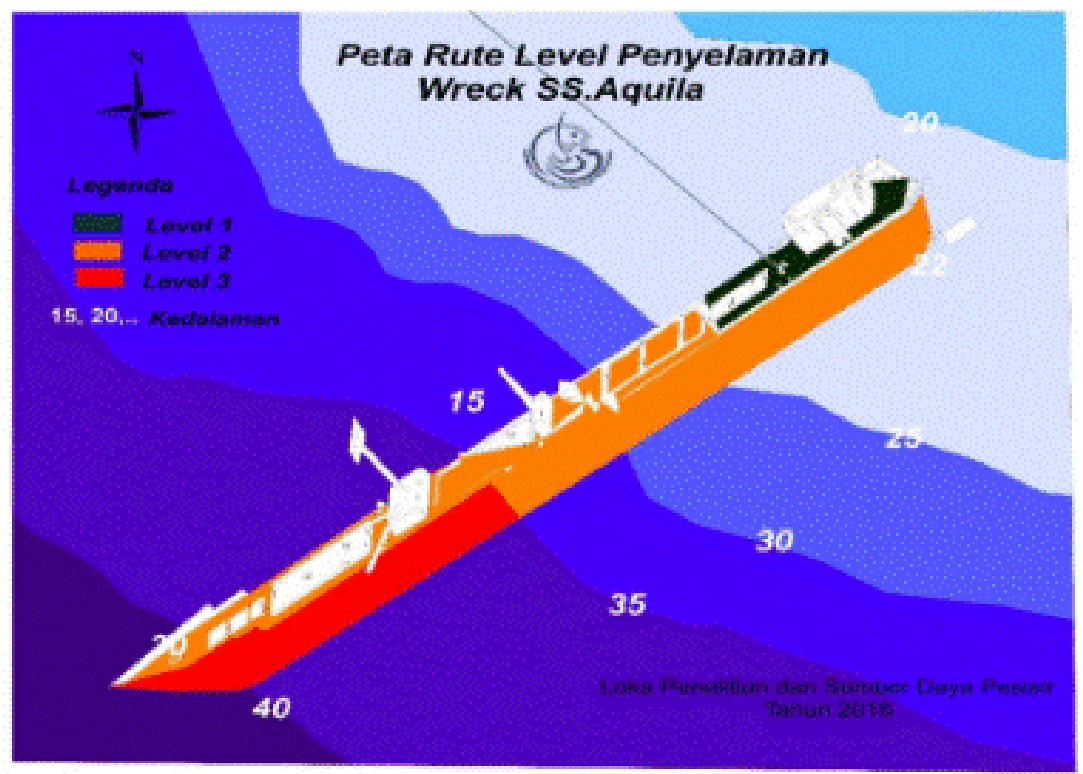

Gambar 4. Jalur level penyelaman kapal SS Aquila. Degradasi warna biru menunjukkan perubahan kedalaman dimana kapal SS aquila berada di slope yang cukup curam. Level 1, 2, dan 3 menunjukkan sepsifikasi penyelam dari open water, advance, hingga master yang mana memerlukan sertifikasi khusus untuk penyelaman dalam.

Figure 4. The level of diving routerof the SS Aquila ship. Blue degradation indicates changes in depth where the SS aquila ship is in a fairly steep slope. Levels 1, 2, and 3 show the specifications of divers from open water, advance, to which master requires special certification for deep diving. 
Kondisi yang berbeda dapat dilihat pada perairan Teluk Ambon Dalam, dimana kondisi dasar perairan yang relatif dangkal berada pada kedalaman antara 0 - 40 $m$ dengan jarak interval kontur yang relatif berjauhan pada tiap kedalaman (Gambar 3).

Pada gambar 4 dapat dijelaskan bahwa level penyelaman tergantung pada kedalaman dari posisi kapal tersebut. Level 1 untuk Semua penyelam yang bersertifikasi atau penyelam non sertifikasi dengan syarat pemandu seorang instruktur, Level 2 Semua penyelam yang bersertifikasi dengan tambahan pengalaman yang sesuai dengan kondisi perairan dengan level 2 ini, khusus untuk penyelaman di lebih dalam dari 18 $\mathrm{m}$, direkomendasikan peselam bersertifikat lanjutan untuk menyelam pada kondisi "overhead environment" level 2, peselam wajib memiliki teknik buoyancy yang memadai, Level 3 Peselam bersertifikasi yang berpengalaman minimum $30 \mathrm{x}$ penyelaman dengan didalamnya memiliki pengalaman pada kondisi level 3, ditambah kewajiban untuk mememiliki sertifikasi jenjang lanjutan. Untuk penyelaman overhead environment level 3, diwajibkan memiliki sertifikat wreck dan/atau cavern.

Kadar salinitas antara salinitas dari perairan Teluk Ambon Luar berkisar antara 33,8-34,4 \%o dengan nilai rata-rata $34,16 \%$. Nilai DO pada hasil pengamatan berkisar antara 4,42-5,03 ppm dengan rata-rata 4,82 ppm.

Rata-rata nilai $\mathrm{pH}$ sebesar 7,78 dengan kisaran nilai antara 7,01-8,34 masih diatas standar baku mutu air laut yang telah ditetapkan yaitu 7-8,5. Besarnya nilai $\mathrm{pH}$ sangat menentukan dominasi fitoplankton yang mempengaruhi tingkat produktivitas primer suatu perairan dimana keberadaan fitoplankton didukung oleh ketersediaanya nutrien di laut (Megawati et al., 2014).

Minyak dan lemak hasil analisis lab pada beberapa sampel yang diambil pada saat pengamatan berada pada kisaran 0,0019-0,0042 mg/l. Kekeruhan (Turbidity) pada perairan Teluk Ambon berkisar antara 0-0,25 NTU. Kekeruhan sangat berpengaruh terhadap kehidupan biota, dan jumlah intensitas cahaya matahari
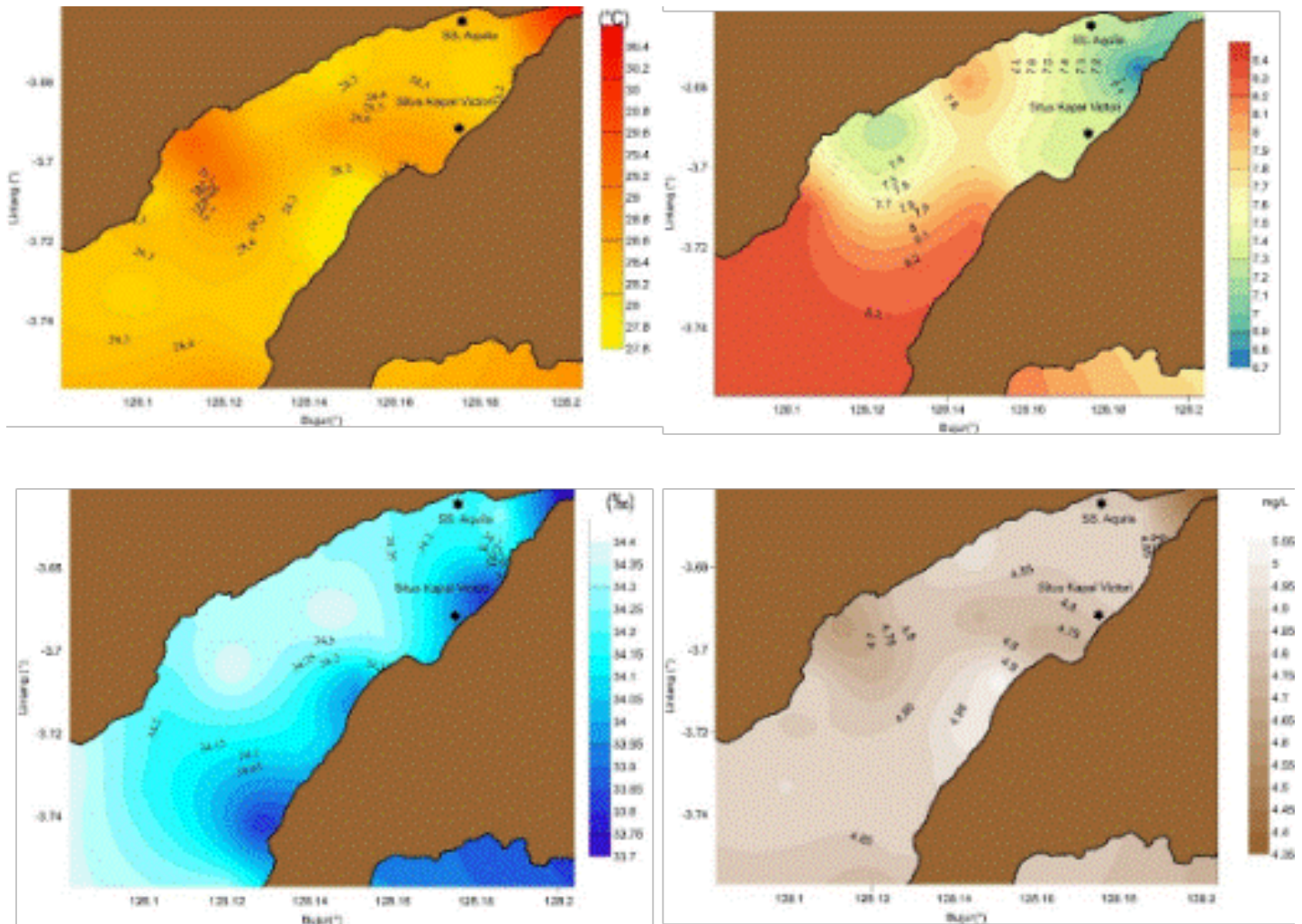

Gambar 5. Sebaran kondisi kualitas perairan disekitar situs SS Aquila; sebaran suhu (kiri atas), sebaran salinitas (kiri bawah), sebaran pH (kanan atas), dan sebaran DO (kanan bawah)

(Sumber: Rahmawan \& Gemilang, 2017)

Figure 5. Distribution of water quality conditions around the SS Aquila site; temperature distribution (top left), salinity distribution (bottom left), distribution of $\mathrm{pH}$ (top right), and distribution of DO (bottom right)

(Source: Rahmawan \& Gemilang, 2017) 
yang mampu menembus sampai kedalaman laut.

Menurut Rahmawan dan Gemilang (2017) kondisi perairan Teluk Ambon masih dalam kondisi baik walaupun beberapa parameter kualitas perairan berada diatas standar baku mutu. Sebaran kondisi kualitas perairan disajikan pada Gambar 5. Lokasi SS Aquila merupakan salah satu wilayah yang rentan terhadap masukan bahan pencemar (sampah, sedimen) karena lokasinya yang dekat dengan dermaga pertamina dan terletak diantara beberapa muara sungai.

Kondisi lingkungan di sekitar kapal tenggelam menghasilkan beberapa resiko yang mengancam seperti adanya cemaran sampah dan banyaknya muara sungai seperti Sungai Wayame yang memberikan asupan sedimen yang cukup signifikan sehingga menyebabkan kekeruhan pada perairan dan sedimentasi yang tinggi.

Berdasarkan hasil perhitungan menurut metode STORET, maka total skor atau indeks STORET dari kualitas perairan permukaan Teluk Ambon adalah -13 pada permukaan laut, -15 pada kedalaman $2 \mathrm{~m}, 4 \mathrm{~m}$, $16 \mathrm{~m}$ dan termasuk dalam kategori $\mathrm{B}$ atau tercemar sedang.

Hasil perhitungan parameter kualitas perairan Teluk Ambon Luar masih dalam keadaan tercemar sedang sesuai Standar Baku Mutu Kepmen LH No. 51 Tahun 2004 meskipun ada beberapa parameter yang melebihi dari standar baku mutu yang telah ditetapkan. Menurut Aughy (2016) Teluk Ambon sudah mengalami penurunan kualitas perairan semenjak tiga puluh tahun terakhir ini namun masih diatas standar baku mutu air laut yang ditetapkan oleh Kementerian Lingkungan Hidup. Penurunan kualitas perairan tersebut disebabkan karena terdapatnya sampah plastik dan limbah rumah tangga yang berada pada kawasan Perairan Teluk Ambon (Gambar 6). Perubahan-perubahan diatas akan mempengaruhi berbagai parameter kualitas air perairan Teluk Ambon (Tuahatu \& Simon, 2008). Kualitas perairan Teluk Ambon terus mengalami penurunan seiring dengan meningkatnya aktivitas di sekitar teluk (Gemilang et al., 2017).

Peningkatan kegiatan yang terjadi pada kawasan Teluk Ambon, akan meningkatkan pemanfaatan lahan, sehingga menimbulkan implikasi terhadap kualitas perairan dan ekosistem pesisir (mangrove, lamun dan terumbu karang) (Asyiawati et al., 2010).

Penambahan konsentrasi limbah baik yang berasal dari darat maupun dari aktivitas laut, akan berdampak terhadap perubahan komponen fisik, kimia dan biologis teluk secara keseluruhan (Selanno, 2009).

Pada Gambar 6 merupakan kondisi yang didapatkan dari hasil pengamatan secara visual perairan dasar laut dan permukaan laut yang ada di kawasan Wayame. Gambar 6 (a) terdapat adanya bekas ban yang tenggelam dan

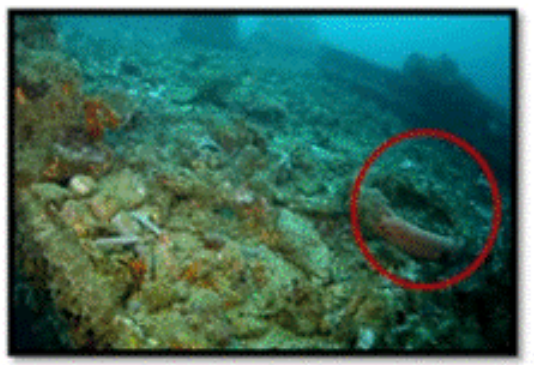

a)

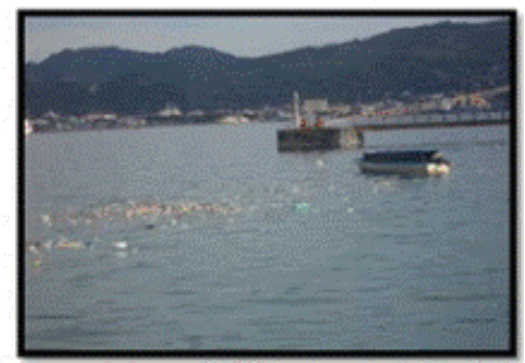

b)

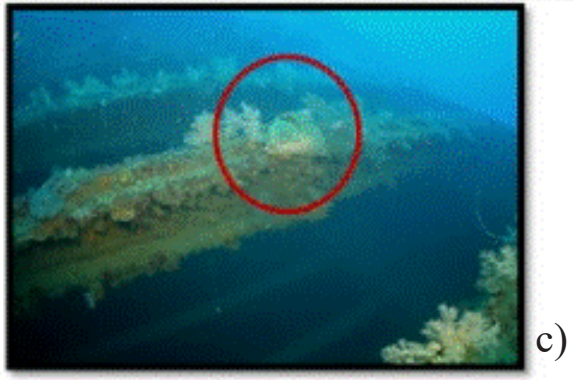

Gambar 6. Fenomena pencemaran sampah di Teluk Ambon a) sampah yang menimbun badan kapal, b) sampah yang mengapung disekitar lokasi situs, c) sampah plastik yang tersangkut bagian kapal.

Figure 6. Phenomenon of trash pollution in Ambon Coastal Bay a) garbage that hides the ship's body, b) garbage that floats around the site, c) plastic waste caught in the ship's part. 
mengendap pada bagian lantai kapal tenggelam SS. Aquila, gambar 6 (b) adanya cemaran sampah rumah tangga yang terbawa oleh arus permukaan, gambar 6 (c) ditemukannya karung bermuatan yang tenggelam dan tersangkut pada bagian kargo kapal tenggelam.

Nilai laju sedimentasi dari hasil penambat sedimen pada beberapa titik pengukuran terlihat variasi nilai laju sedimentasi. Nilai laju sedimentasi rata-rata tertinggi berada pada penambat sedimen yang berada pada bagian lokasi pengamatan kapal SS Aquila dengan laju sedimentasi $0,003 \mathrm{~g} . \mathrm{m}^{-2}$.hari ${ }^{-1}$ hingga $0,0005 \mathrm{~g} \cdot \mathrm{m}^{-2}$. hari $^{-1}$. Pada lokasi kapal SS Aquila kondisi perairan cukup variatif bergantung pada kondisi pasang surut sehingga kencederungan sedimen lebih mudah untuk terendapkan pada lokasi kapal SS Aquila pada saat surut perbani dan peningkatan suspensi sedimen pada kondisi pasang purnama.

\section{KESIMPULAN DAN SARAN}

Berdasarkan kondisi terkini dan nilai historisnya, situs kapal tenggelam SS Aquila yang terdapat di perairan Desa Wayame, Kecamatan Teluk Ambon, Maluku dapat ditetapkan sebagai Kawasan Konservasi Maritim Sesuai dengan Permen KP No. 17 Tahun 2008 pasal 7 huruf b. Selain itu, berdasarkan keberadaaan kapal dan kondisi perairan, Teluk Ambon cukup sesuai untuk mendukung untuk pengembangan wisata bahari. Kondisi hidro-oseanografi di sekitar situs cukup sesuai untuk wisata selam minat khusus. Namun kondisi kualitas perairan sekitar situs masuk dalam kategori tercemar sedang dengan kategori B, sehingga perlu dilakukan pembatasan terhadap sampah dan polutan ke Teluk Ambon agar dapat dijadikan area wisata selam.

Ancaman limbah sampah dan tumpahan minyak menjadi pemicu kerentanan sumber daya wisata arkeologi laut di Teluk Ambon. Beberapa tindakan terhadap perlindungan dan pelestarian situs SS Aquila seperti memberikan sosialisasi dan info rinci mengenai keberadaan situs, dan menjaga kondisi perairan agar situs SS Aquila tetap lestari.

Data yang digunakan hanya mewakili periode bulan tertentu, sehingga untuk melengkapi data sepanjang tahun sangatlah perlu penelitian lanjutan dikarenakan kondisi fisik dan kimia perairan yang cukup fluktuatif dan selalu berubah berdasarkan musim.

\section{UCAPAN TERIMA KASIH}

Ucapan Terimakasih disampaikan kepada Loka Riset Sumberdaya dan Kerentanan Pesisir (LRSDKP) atas DIPA anggaran riset 2016 di Teluk Ambon, Pieter Moe'in Manihin, Pari Diver Ambon sebagai informan dan semua pihak yang membantu dalam penyelesaian artikel ini.

\section{DAFTAR PUSTAKA}

Adibrata, S. (2007). Tidal Analysis in Karampuang Island, West Sulawesi Province. Journal Akuatik., 1(1), 1-6.

Ardiwidjaja, R. (2017). Pelestarian Tinggalan Budaya Bawah Air: Pemanfaatan Kapal Karam sebagai Daya Tarik Wisata Selam. AMERTA, 35(2), 133-148.

Asyiawati, Y., Yulianda, F., Dahuri, R., Sitorus, S. R., \& Susilo, S. B. (2010). Status Ekosistem Pesisir Bagi Perencanaan Tata Ruang Wilayah Pesisir Di Kawasan Teluk Ambon. Jurnal of Perencanaan Wilayah dan Kota, 10(1), 1-7.

Aughy. (2016). Kualitas Teluk Ambon 30 Tahun Menurun. Tribun Maluku. Halaman Web: http://www.tribunmaluku.com/2016/10/kualitas-teluk-ambon-30tahun-terakhir-menurun.html. Diakses pada tanggal 28 Oktober 2017 Pukul 10.35 WIB.

Carducci, G. (2002). New Developments in the Law of the Sea: The UNESCO Convention on the Protection of Underwater Cultural Heritage. American Journal of International Law, 96(2), 419-434.

Gemilang, W. A., Rahmawan, G. A., \& Wisha, U. J. (2017). Kualitas Perairan Teluk Ambon Dalam Berdasarkan Parameter Fisika dan Kimia pada Musim Peralihan I. EnviroScienteae, 13(1), 79-90.

Handoko, W. (2007). Sumberdaya Arkeologi Menuju Industri Pariwisata di Maluku: Masalah, Peluang, Tantangan dan Solusinya. Kapata Arkeologi, 119-139.

Koriyandi, A., Hamdani, H., \& Salim, D. (2016). Analisis Kesesuaian Wisata Diving di Kawasan Perairan Pulau Kunyit Sebelah Timur Kecamatan Pulau Laut Tanjung Selayar Kabupaten Kotabaru. Enviro Scienteae, 12(3), 181-193.

Megawati, C., Yusuf, M., \& Maslukah, L. (2014). Sebaran kualitas perairan ditinjau dari zat hara, oksigen terlarut dan $\mathrm{pH}$ di perairan selat bali bagian selatan. Journal of Oceanography, 3(2), 142-150.

Rahmawan, G. A., \& Gemilang, W. A. (2017). Status Baku Mutu Air Laut Perairan Teluk Ambon Luar Untuk Wisata Bahari Kapal Tenggelam SS Aquila. EnviroScienteae, 13(2), 139-149.

Selano, D. A. J. (2009). Analisis hubungan antara beban pencemaran dan konsentrasi limbah sebagai dasar pengelolaan kualitas lingkungan perairan Teluk Ambon. Disertasi. Sekolah Pasca Sarjana IPB. Bogor. Hlm, 399.

Simanjuntak, B. L. G., Handoyo, D. S., \& Nugroho. (2012). Analisis Batimetri dan Komponen Pasang Surut untuk Penentuan Kedalaman Tambahan Kolam Dermaga di Perairan Tanjung Gundul Bengkayang - Kalimantan 
Barat. Jurnal Oseanografi. 1(1), 1-8.

Soeprapto. (1999). Survei Hidrografi. Gadjah Mada University Press, Yoyakarta, $202 \mathrm{hlm}$.

Tony, A. (2013). SS Aquila (+1958). Webpage (http://www. wrecksite.eu/wreck.aspx?205640). Diakses pada tanggal 18 oktober 2016 15:45 WIB.

Tuahatu Juliana W \& Simon Tubalawony. (2008). Sebaran Nitrat dan Fosfat Pada Massa Air Permukaan Selama Bulan Mei 2008 Di Teluk Ambon Bagian Dalam. Triton (Jurnal Manajemen Sumber daya Perairan, 5(1), 34-40.

Turang. (2016). Aksi-Aksi Pilot PRRI Permesta. Halaman web: http://beritanusantara.co.id/index.php/ berita/single/b/293/Aksi_Aksi_Pilot_PRRI PERMESTA _3. Diakses pada Tanggal 28 Oktober 2017 Pukul 19.37 WIB.

Wisha, U. J., Rahmawan, G. A., Ridwan, N. N. H., and Kusumah, G. (2017). Oil Spill Analysis on Ambon Bay, Moluccas, Indonesia: Its Influence on the SS Aquila Shipwreck Site. The 4th APCONF (AsiaPacific Conference on Underwater Cultural Heritage proceeding, Hong Kong, August 2017. 
